\title{
1 Grass leaves as potential hominin dietary resources
}

3 Oliver C. C. Paine ${ }^{\mathrm{a}, *}$, Abigale Koppa ${ }^{\mathrm{b}}$, Amanda G. Henry ${ }^{\mathrm{c}}$, Jennifer N. Leichliter ${ }^{\mathrm{a}}$,

4 Daryl Codron $^{\mathrm{d}, \mathrm{e}}$, Jacqueline Codron ${ }^{\mathrm{f}}$, Joanna E. Lambert ${ }^{\mathrm{a}, \mathrm{g}}$, Matt Sponheimer ${ }^{\mathrm{a}}$

a Department of Anthropology, University of Colorado Boulder, Boulder, CO 80309 USA

7 b Department of Ecology and Evolution, State University of New York, Stony Brook, New York 11794,

8 U.S.A.

9 c Faculty of Archaeology, Leiden University, Einsteinweg 2, 2333CC Leiden, The Netherlands.

10 d Florisbad Quaternary Research Department, National Museum, PO Box 266, Bloemfontein, 9300,

11 South Africa

12 e Centre for Environmental Management, University of the Free State, PO Box 339, Bloemfontein, 9300,

13 South Africa

14 f Institut für Geowissenschaften, AG für Angewandte und Analytische Paläontologie, Johannes

15 Gutenberg-Universität Mainz, 55128 Mainz, Germany

16 g Department of Environmental Studies, University of Colorado Boulder, Boulder, CO 80309 USA

* Corresponding Author: oliverpaine@ colorado.edu (Oliver Paine)

Abstract

Discussions about early hominin diets have generally excluded grass leaves as a staple food resource, despite their ubiquity in most early hominin habitats. In particular, stable carbon isotope studies have shown a prevalent $\mathrm{C}_{4}$ component in the diets of most taxa, and grass leaves are the single most abundant $\mathrm{C}_{4}$ resource in African savannas. Grass leaves are typically portrayed as having little nutritional value (e.g., low in protein and high in fiber) for hominins lacking specialized digestive systems. It has also been argued that they present mechanical challenges (i.e., high toughness) for hominins with bunodont dentition. Here, we compare the nutritional and mechanical properties of grass leaves with the plants growing alongside them in African savanna habitats. We also compare grass leaves to the leaves consumed by other hominoids and demonstrate that many, though by no means all, compare favorably with the nutritional and mechanical properties of known primate foods. Our data reveal that grass leaves exhibit tremendous variation and suggest that future reconstructions of hominin dietary ecology take a more nuanced approach when considering grass leaves as a potential hominin dietary resource.

Keywords: grass; dietary fiber; protein; toughness; hominin diet

\section{Introduction}

Diet has long been considered a prime mover in hominin evolution, but links between diet and early hominin differentiation have become more debatable as new 
methods and data have become available. A growing body of evidence is challenging

43 many traditional interpretations of hominin dietary behavior (for discussion, see Ungar

44 and Sponheimer, 2011). For instance, Paranthropus boisei exhibits some of the starkest

45 morphological adaptations to diet of any known hominin species (Rak, 1983, 1988),

46 and some have argued that its hyper-robust craniodental architecture was necessary for

47 the habitual consumption of hard, obdurate foods such as nuts and seeds (Leakey, 1959;

48 Tobias, 1967; Jolly, 1970; Rak, 1983; Demes and Creel, 1988; Strait et al., 2008, 2013;

49 Constantino et al., 2010, 2011; Smith et al., 2015), yet dental microwear evidence

50 reveals no hard-object consumption by $P$. boisei (Ungar et al., 2008, 2012; Grine et al.,

51 2012). Moreover, some argue that craniodental robusticity can result from the

52 mechanical challenge posed by diets of tough, low quality foods requiring prolonged

53 and repetitive loading of the chewing apparatus (Ungar and Hlusko, 2016; Daegling

54 and Grine, 2017; see also Hylander, 1988, for earlier arguments about craniodental

55 robusticity as an evolutionary response to repetitive loading).

Additionally, stable carbon isotope studies show that $\mathrm{C}_{4}$ foods (i.e., foods enriched in ${ }^{13} \mathrm{C}$ ) became increasingly significant portions of hominin diets beginning at least 3.7 Ma-culminating with P. boisei, whose diet was 75-80\% $\mathrm{C}_{4}$ (van der Merwe et al., 2008; Cerling et al., 2011; Ungar and Sponheimer, 2011; Lee-Thorp et al., 2012; Sponheimer et al., 2013; Levin et al., 2015). Moreover, the degree of postcanine megadontia and mandibular robusticity exhibited by early hominin species is positively correlated with the amount of $\mathrm{C}_{4}$ foods they consumed, suggesting that the inherent properties of these foods may have contributed to australopith craniodental adaptations

64 (Sponheimer et al., 2013).

Hominins may have consumed foods enriched in ${ }^{13} \mathrm{C}$ either as primary consumers of plants using the $\mathrm{C}_{4} / \mathrm{CAM}$ photosynthetic pathway and/or as secondary consumers eating animals that consume significant quantities of $\mathrm{C}_{4}$ vegetation (e.g., grazing ungulates such as wildebeest and zebra). However, while faunal resources were a likely source of dietary carbon, few would argue that meat consumption was a major component of early hominin diet, despite recent discoveries revealing hominin tool use before $3 \mathrm{Ma}$ (McPherron et al., 2010; Harmand et al., 2015). Similarly, plants using CAM photosynthesis (e.g., succulents) were potentially consumed, but are relatively scarce within most savanna habitats. Thus, despite contributions from faunal and CAM resources, it is most likely that $\mathrm{C}_{4}$ plants were the primary source of dietary carbon for early hominins with high $\mathrm{C}_{4}$ isotopic signatures such as P. boisei, Paranthropus aethiopicus, and Australopithecus bahrelghazali.

Of the roughly 7500 species of plants that use the $\mathrm{C}_{4}$ photosynthetic pathway, most $(\sim 80 \%)$ are monocots in the families Poaceae and Cyperaceae-tropical grasses

79 ( 4500 species) and sedges ( 1500 species), respectively (Sage et al., 1999; Sage,

80 2004). Thus, the bulk of $\mathrm{C}_{4}$ plant biomass available to African herbivores is located in 
savanna and/or wetland habitats. While definitions of 'savanna' can be debated, it is generally agreed upon that a mostly continuous layer of grasses is a key, if not definitive component of savanna habitats (for discussion, see Scholes and Archer, 84 1997).

We are now faced with the task of determining which $\mathrm{C}_{4}$ plants contributed to
in diets (grasses and/or sedges) and how they were utilized. Specifically, were hominin diets (grasses and/or sedges) and how they were utilized. Specifically, were certain plant parts such as seeds and storage organs targeted for consumption? These questions become particularly important for species with highly derived craniodental morphology, such as P. boisei (Wood and Constantino, 2007; Ungar and Sponheimer, 2011; Daegling and Grine, 2017).

Grass and sedge species possess several anatomical structures that may serve as food for a consumer, including underground storage organs (USOs such as tubers, rhizomes, and corms), seeds, and leaves (which include the blade, collar, and sheath). Scholars have more readily accepted some of these anatomical elements of grasses and sedges as hominin foods. For example, some (e.g., van der Merwe et al., 2008; Dominy et al., 2012) have argued that $\mathrm{C}_{4}$ sedges were a likely resource because they often have relatively large USOs that are unavailable to most African herbivores. This underutilized resource would be available to hominins with rudimentary tools, such as digging sticks, and thus would have represented a novel feeding niche ripe for hominin exploitation (Hatley and Kappelman, 1980; Hernandez-Aguilar et al., 2007). Also, sedge (and other) USOs are available year-round and are often portrayed as being both nutrient-dense and mechanically suitable for hominin dental adaptations (Hatley and Kappelman, 1980; Laden and Wrangham, 2005; Dominy et al., 2008; Wrangham et al., 2009; Dominy, 2012; Lee-Thorp et al., 2012).

Similarly, the seeds of $\mathrm{C}_{4}$ grasses have been proposed as a hominin food by some researchers (Jolly, 1970; Peters and Vogel, 2005). Like sedge USOs, they are perceived as nutritionally adequate and possessing physical properties (small and somewhat hard) well suited for hominin consumption. It is also worth noting that modern humans consume vast quantities of grass seed today (e.g., maize, rice, wheat) and have done so for millennia (van Oudtshoorn, 2012).

In contrast, grass leaves are not considered a viable hominin food by most because they are generally regarded as offering little nutritional value (low in protein and high in fiber) and having mechanical properties (particularly, measures of toughness) that are ill-suited for hominins lacking the occlusal relief and/or hypsodonty seen in leaf-eating primates or grazing herbivores (Yeakel et al., 2007; Lee-Thorp et al., 2012; Fontes-Villalba et al., 2013; Macho, 2014; Yeakel et al., 2014). However, it is noteworthy that gramnivory is observed in other omnivorous taxa exhibiting bunodonty such as black bears (Ursus arctos), which are known to eat 31 species of graminoids in Yellowstone National Park (Raia, 2004; Gunther et al., 2014). 
Moreover, because $\mathrm{C}_{4}$ grasses are generally dominant components of savanna landscapes, their leaves often represent the most abundant and accessible biomass for herbivores (Jacobs et al., 1999). Unsurprisingly, grasses represent a major source of nutrition for Papio living in these environments (DeVore and Washburn, 1963; Altmann and Altmann, 1970; Post, 1982; Altmann et al., 1987; Norton et al., 1987; Barton et al., 1993; Barton and Whiten, 1994; Altmann, 1998). From this standpoint, it is possible that grass leaf has been prematurely excluded from reconstructions of hominin diet by some and that when it is considered it is often treated as a monolithic entity in a manner that fails to account for taxonomic, seasonal, and habitat effects which may potentially affect its nutritional and mechanical palatability (e.g., Peters and Vogel, 2005; Lee-Thorp et al., 2012; Yeakel et al., 2014; Macho, 2015).

While no one disputes that many ungulates have dental and digestive adaptations specifically enabling them to subsist on a grass-based diet (Stirton, 1947; White, 1959; Langer, 1974; Janis, 1976; Janis and Fortelius, 1988; Robbins, 2012), Poaceae are incredibly diverse with species ranging from tree-like bamboo with woody growth to softer, strictly herbaceous and 'carpet-like' grasses. This suggests that we should adopt a more nuanced understanding of the diversity of consumption patterns and dietary niches adopted by primary consumers of grasses and that we reassess many assumptions about the potential role of grasses in early hominin dietary ecology.

Here, we investigate the nutritional and mechanical properties of African $\mathrm{C}_{4}$ grass leaves. We wish to make it clear that we are not attempting to describe what hominins did, or did not eat, we are simply interested in testing the hypothesis that grass leaves could have been a significant source of nutrition for early hominins. Moreover, we are not investigating hypotheses concerning the potential evolutionary link between australopith craniodental morphology and the consumption of grass leaves. Clearly, these are important avenues of research but they will ultimately be of limited value if there is a lack of nutritional and mechanical data to support or reject any given hypothesis. It is the goal of this paper to begin to provide these data and to help inform future debates.

\section{Methods}

We collected plant samples from the Cradle Nature Reserve, South Africa (July, 2014, and January, 2015) and Amboseli National Park, Kenya (May, 2016), from transects located in distinct microhabitats (e.g., grassland, woodland, and wetland). Microhabitats were defined according to Reed et al. (2013: Table 1.1). We sampled the most abundant grass, sedge, tree, and forb species as determined according to methods outlined in Stohlgren et al. (1995) ('forbs' in our study represent plants that are neither grasses, sedges, nor trees). All grass species we sampled are $\mathrm{C}_{4}$ and sedges are mixed $\mathrm{C}_{3} / \mathrm{C}_{4}$ species. Samples were separated into their constituent organs for analyses (e.g., 
seed, leaf, and stem).

160 We grouped these samples into broad categories of potential hominin plant 161 foods based on organs/structures known to be eaten by primates: grass leaf, sedge leaf, 162 tree leaf, forb leaf, fruit, inflorescence (from grasses and sedges), and USOs (e.g., 163 rhizomes, bulbs, and corms from grasses, sedges, and forbs). Here, we present mature 164 leaf and inflorescence samples collected only during the wet season to capture 165 nutritional values that best represent the bulk of their growth phase. Newly grown 166 leaves (particularly among grasses) are known to be higher in protein and lower in fiber 167 than mature leaves. Thus, we do not include data for any new growth samples we 168 collected to ensure that our results reflect the properties of leaves during the majority of 169 their life cycles and when they are most abundant. Fruit and USO samples are from 170 both wet and dry seasons as their collection is subject to availability.

171 Toughness was measured in the field on fresh samples using the scissors test on 172 a Lucas Scientific FLS-I portable mechanical tester. Toughness $(R)$ is a measure $\left(\mathrm{J} / \mathrm{m}^{2}\right)$ 173 of the force necessary to propagate a crack through a material (for discussion, see Lucas 174 et al., 2012). When applicable, we performed scissors tests perpendicular to veins 175 and/or midribs within plant tissues in order to capture maximum toughness values. For 176 the same reason, we did not remove exocarps, sheaths, and/or rinds of organs such as 177 fruits and USOs prior to testing. We replicated the scissors test three times per 178 specimen and used the median value for statistical analyses. We could not test some 179 fruit samples due to their small size and heterogeneous structural properties. We dried 180 wet samples in the field in Excalibur ${ }^{\circledR}$ dehydrators at $40^{\circ} \mathrm{C}$, sealed dried samples in 181 paper bags with desiccant, and exported them to the Nutritional and Isotopic Ecology 182 Lab (NIEL) at the University of Colorado Boulder for nutritional analyses.

183 We present results for crude protein (CP) and acid detergent fiber (ADF) as a 184 percentage of dry weight. We chose these measures because they are a widely used 185 proxy for overall forage quality (Robbins, 1983; McNaughton and Georgiadis, 1986; 186 but see discussion for the important factors such as micronutrients and water content). 187 Crude protein was measured with a LECO ${ }^{\circledR}$ FP 528 nitrogen analyzer using the 188 standard \% $\mathrm{N}$ x 6.25 conversion to obtain \% CP. ADF was measured with an ANKOM® 1892000 fiber analyzer.

190 We performed nonparametric comparisons using the Wilcoxon/Kruskal-Wallis 191 test in JMP® Pro 13.0.0 as few of our datasets are normally distributed. Multiple 192 comparisons were performed using the Steel-Dwass all pairs test. See Supplementary 193 Online Material (SOM) 1 for summary statistics of all samples and measures recorded.

\section{Results}

196 Nutritional data

197 Plant foods differed significantly in protein content $(p<0.0001)$. Grass leaves 
have lower protein levels than forb $(p=0.0438)$ and tree leaves $(p=0.0397)$, but higher levels than sedge leaves $(p=0.0083)$ and USOs $(p<0.0001)$ (Figure 1). Four of the five extreme outliers in the USO category are the stolons of Cynodon plectostachyus; the fifth is from the rhizome of Typha capensis. Grass leaves, fruits, and inflorescences do not differ significantly in protein content. Grass leaves exhibit a wide range of values: ranging from protein deficient $(<5 \%)$ to relatively protein-rich $(>15 \%)$, with some samples having higher values than the leaves of trees growing alongside them (> $20 \%$ ). Indeed, protein values for grass leaves span almost the entire range of all other values combined, although the distribution is bimodal with each mode normally distributed (Shapiro-Wilk test: lower mode, $p=0.5682$; higher mode, $p=0.7985$ ). The four species representing the higher cluster have mean CP as follows: Panicum sp. (17.4\%), Sporobolus ioclados (19.5\%),

C. plectostachyus (20.9\%), and Setaria 210 verticillata $(21.0 \%)$.

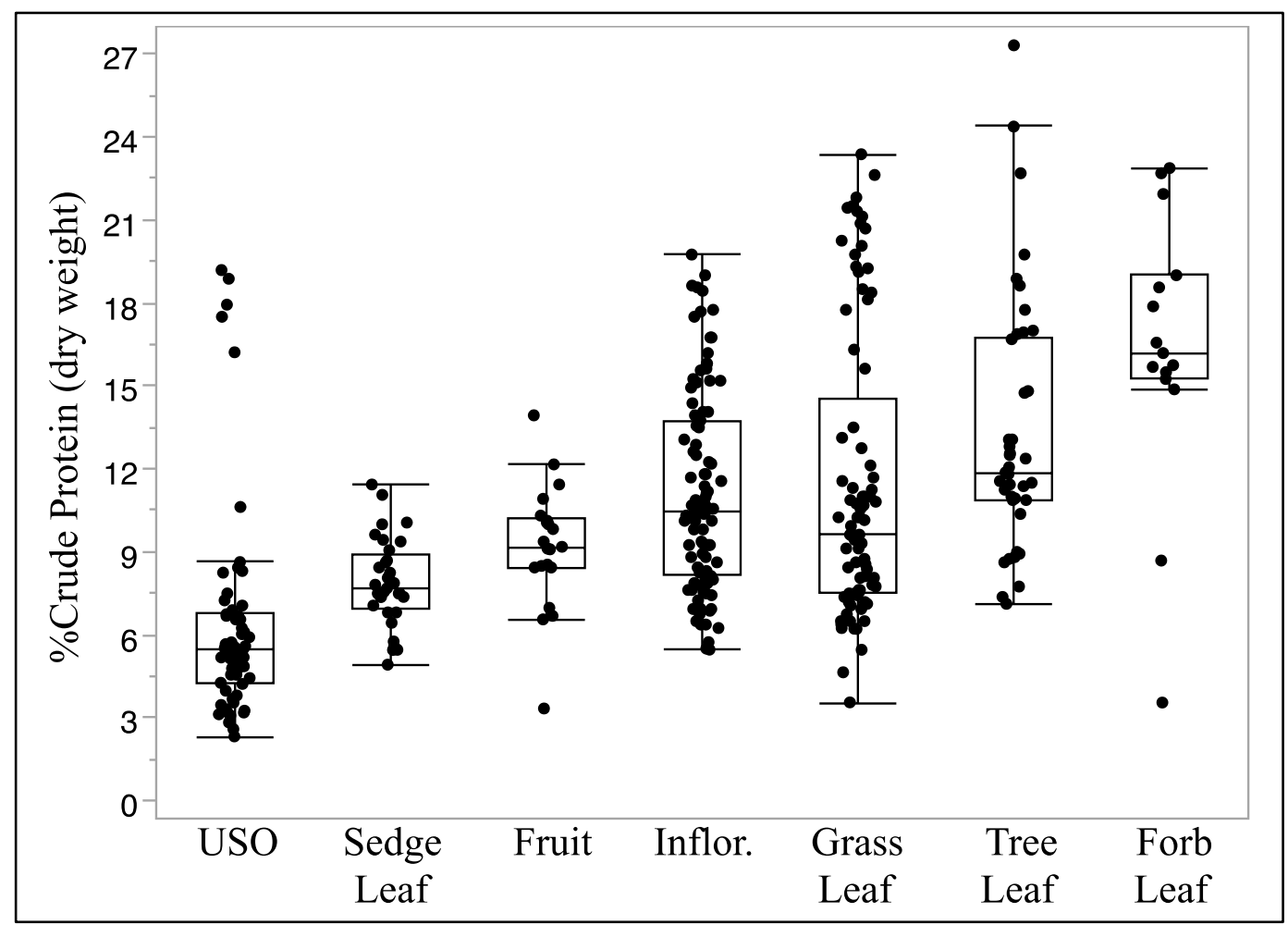

Figure 1. Crude protein content (\%) of plant parts within savanna habitats known to be consumed by primates. (Wilcoxon/Kruskal-Wallis test, $p<0.0001$ ). Categories are arranged in ascending order by mean value. Boxes represent the $25^{\text {th }}-75^{\text {th }}$ percentiles, the lines within them are the medians, the whiskers show data within 1.5 times the interquartile ranges, and the dots outside of the whiskers are outliers. "Inflor." is the abbreviation of inflorescence.

Grass leaves have the highest median value for ADF content (35.9\%) compared 
to all other categories, and that they are significantly higher than forb and tree leaves ( $p$ $<0.0001)$ and fruit $(p<0.0001$; Figure 2). However, once again, grass leaves exhibit a high degree of variation. The distribution of grass leaf ADF values is bimodal, though it is less pronounced than observed in our protein values. The four grass leaf species with the highest crude protein among grass leaves analyzed also have the lowest levels of ADF with their mean values as follows: C. plectostachyus (16.1\%), Se. verticillata (22.4\%), Sp. ioclados (24.4\%), and Panicum sp. (25.5\%).

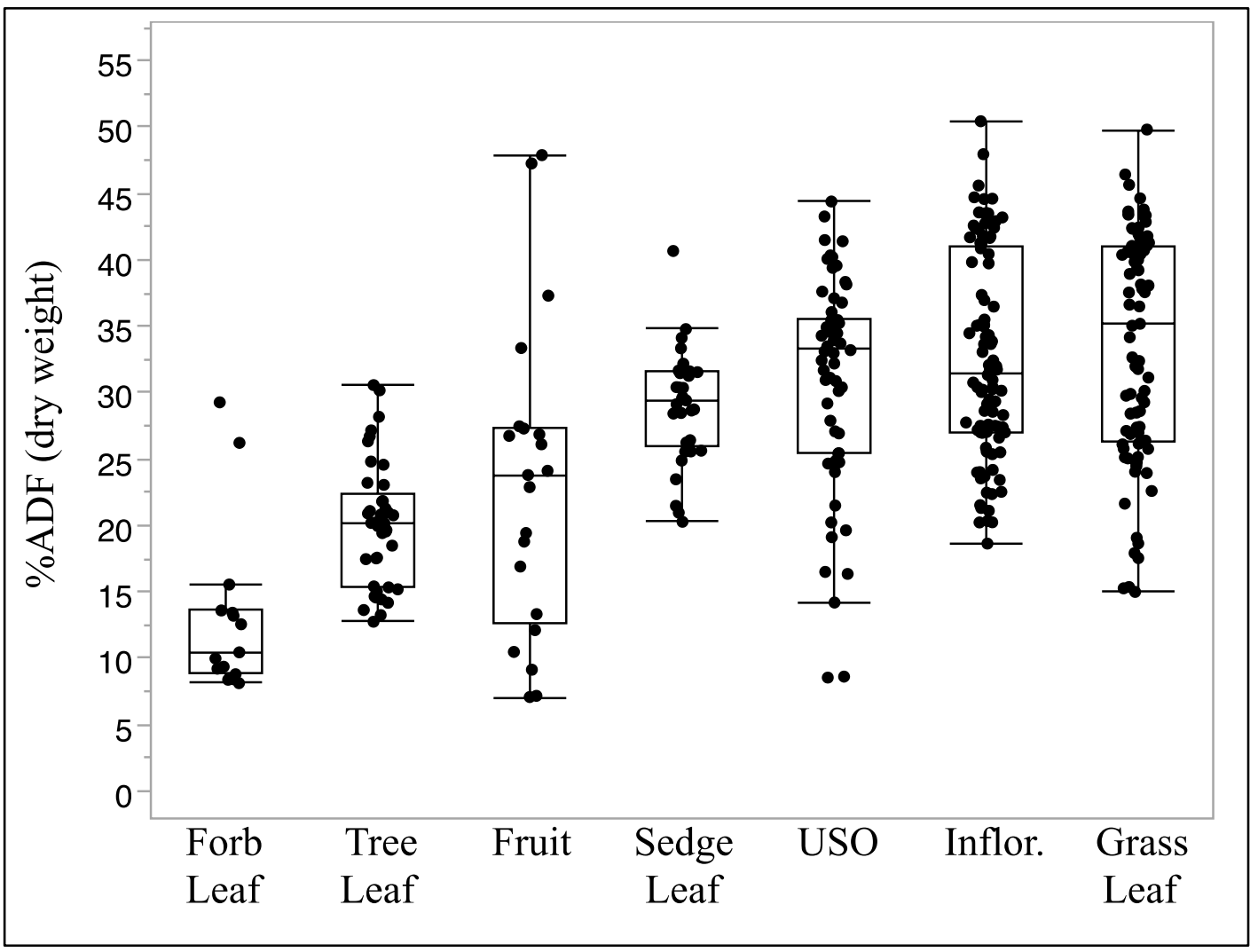

Figure 2. Acid detergent fiber content (\%) of plant parts within savanna habitats known to be consumed by primates (Wilcoxon/Kruskal-Wallis test, $p<0.0001$ ). Categories are arranged in ascending order by mean value. Boxes represent the $25^{\text {th }}-75^{\text {th }}$ percentiles, the lines within them are the medians, the whiskers show data within 1.5 times the interquartile ranges, and the dots outside of the whiskers are outliers. "Inflor." is the abbreviation of inflorescence.

\section{Mechanical data}

Mechanically, grass leaves are significantly tougher than fruit $(p=0.0062)$, forb leaves $(p=0.0002)$, and tree leaves $(p<0.0001)$. Only USOs are significantly tougher than grass leaves ( $p=0.0175$; Figure 3 ). Yet, similar to CP and ADF, grass leaf toughness values span almost the entire range of our samples (with the exception of 
240 USOs), with some having values in line with tree leaves and fruits known to be primate 241 foods.

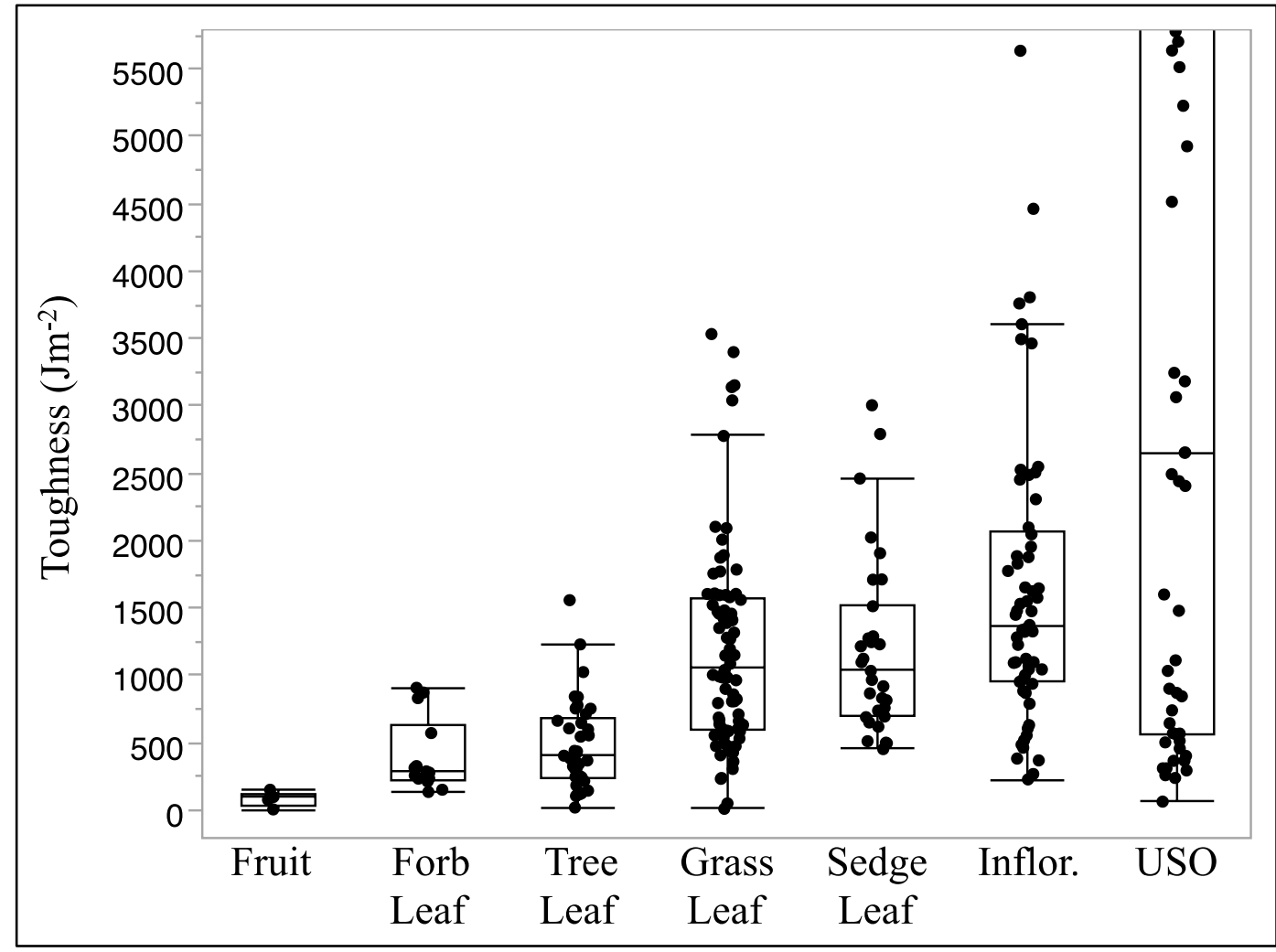

Figure 3. Toughness values $\left(\mathrm{J} / \mathrm{m}^{2}\right)$ of plant organs within savanna habitats known to be consumed by primates (Wilcoxon/Kruskal-Wallis test, $p<0.0001$ ). The $\mathrm{y}$-axis has been capped at $6000 \mathrm{~J} / \mathrm{m} 2$ as primates rarely consume foods beyond this limit. Categories are arranged in ascending order by mean value. Boxes represent the $25^{\text {th }}-75^{\text {th }}$ percentiles, the lines within them are the medians, the whiskers show data within 1.5 times the interquartile ranges, and the dots outside of the whiskers are outliers. "Inflor." is an abbreviation of inflorescence.

\section{Discussion}

Grass leaves within our transects, taken as a whole, have relatively low crude protein content, high fiber content, and high toughness values. At this broad scale, common assumptions about their merit as potential hominin foods appear to be warranted. However, it is clear that grass leaves-like many plant species and plant foods commonly consumed by primates - are diverse with regard to their nutritional and mechanical properties and our data indicate that $\sim 25 \%$ of our samples $(C$. plectostachyus, Se. verticillata, Sp. ioclados, Panicum sp.) potentially represent highquality resources within their respective habitats. As with many other generalizations about diet and nutrition, this suggests that we rethink earlier assumptions about what 
constitutes a 'quality food'. Many generalizations have been made, for example, about the nutritional properties of fruit versus leaves, with fruit representing a 'high-quality' food high in easily digested mono- and disaccharides and low in fiber. Leaves, conversely, have been classically generalized as being low in simple sugars and high in fiber. Despite these assumptions (prevalent throughout the literature), nutritional analyses have revealed extreme variance in fruit and leaf nutritional composition. For example, analyses of the sugar and fiber composition of leaves and fruits consumed by catarrhines in Kibale National Park, Uganda, have demonstrated that fruit can have similar (or lower) sugars than the mean sugar value for leaves, and that the variance in monosaccharides of leaves overlaps that of fruit (Danish et al., 2006). Indeed, as more nutritionally explicit analyses are conducted on wild foods, it is increasingly evident that we should revisit all such generalizations, including those made about grasses (Simpson and Raubenheimer, 2012; Lambert and Rothman, 2015; Rothman et al., 2015).

As noted above, grass leaf is generally the most abundant plant biomass in savanna ecosystems (Jacobs et al., 1999). Thus, if we cast aside earlier generalizations made about grass leaf macronutrient composition, and consider that $25 \%$ of the grass leaves within any given habitat can be palatable to species without specialized digestive strategies, this further increases their value to herbivore consumers because encounter and harvesting rates will be relatively high. At the very least, the notion that all grass leaves growing on savanna landscapes were unsuitable for hominin consumers needs reconsideration, particularly when we compare our samples with published values for other hominoid foods.

\section{Hominoid comparisons}

When we divide our samples into 'high-protein' and 'low-protein' categories based on their bimodal distribution for crude protein content, we find that our high-protein grasses (SOM 1) compare very favorably against other hominoid leaf foods. In the figures below, we compare CP (Figure 4) and ADF (Figure 5) of the leaves consumed by gorillas from the Virunga Mountains of Rwanda and Zaire (Waterman et al., 1983), the Lopé Reserve, Gabon (Rogers et al., 1990), Bai Hokou, Central African Republic (Remis et al., 2001), and the Bwindi Impenetrable National Park, Uganda (Rothman et al., 2006). We also include data provided by Rogers et al. (1990) for leaf foods rejected by the Lopé Reserve gorillas. These comparisons reveal that our high-protein grasses have protein contents equivalent to, and in one instance higher than, the leaves consumed by gorillas (CP in high quality grass leaves is significantly higher than in the leaves eaten by the Virunga gorillas; $p=0.0019$ ). 


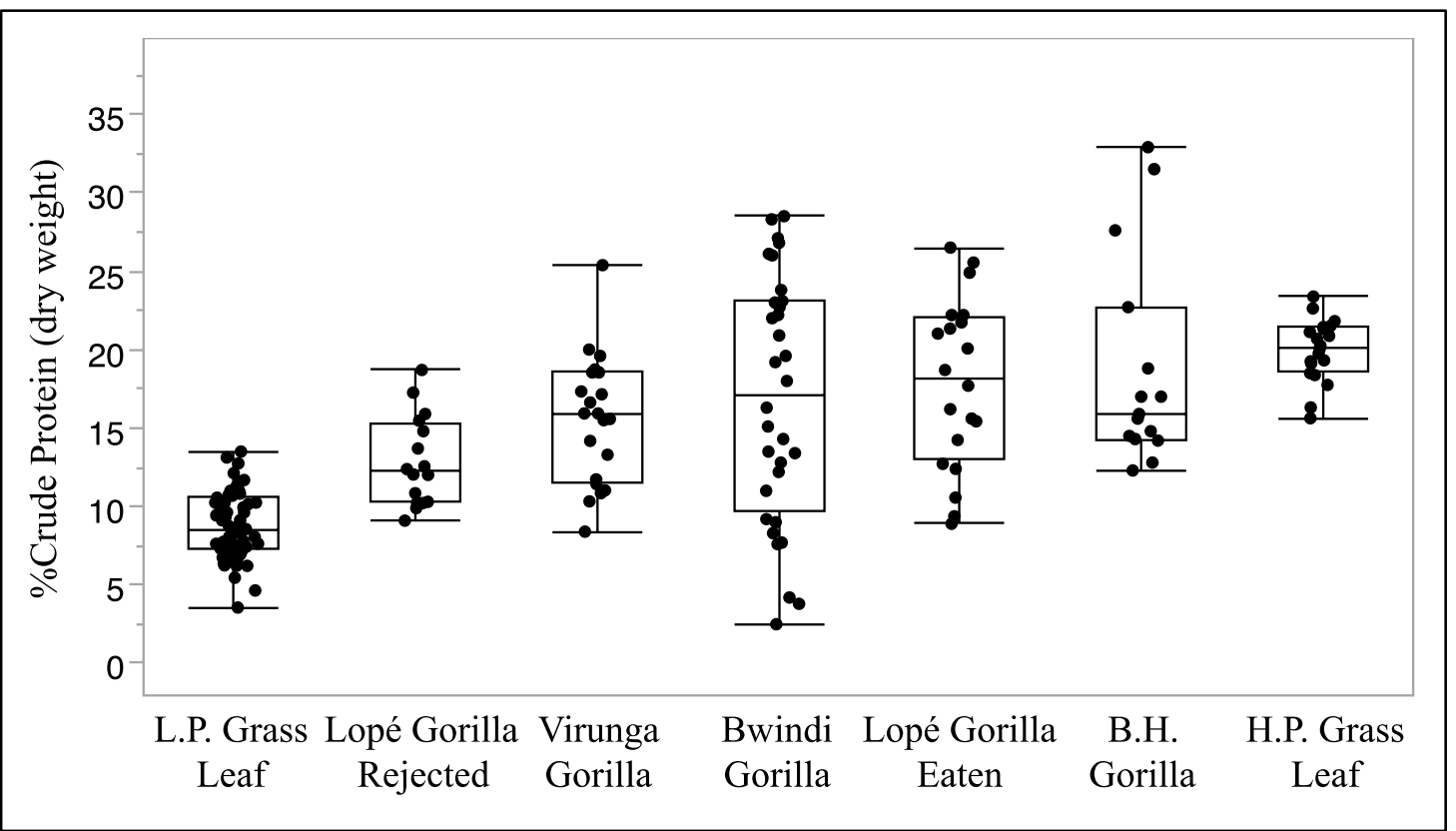

300 Figure 4. Crude protein (\%) of low-protein (L.P.) and high-protein (H.P.) grass leaves 301 compared to leaves eaten, and rejected, by gorillas arranged in ascending order by mean value. Boxes represent the $25^{\text {th }}-75^{\text {th }}$ percentiles, the lines within them are the medians, the whiskers show data within 1.5 times the interquartile ranges, and the dots outside of the whiskers are outliers (Wilcoxon/Kruskal-Wallis test, $p<0.0001$ ). Low-protein grasses are significantly different than all other categories $(p<0.0001)$ and highprotein grasses are significantly different than Virunga gorilla leaf foods $(p=0.0019)$ and leaves that Lopé gorillas reject (Steel-Dwass all pairs). Gorilla data from Waterman et al., 1983; Rogers et al., 1990; Remis et al., 2001; Rothman et al., 2006.

Our comparisons of ADF reveal a similar trend, albeit more complex (Figure 5). Our high-protein grass leaves are significantly lower in ADF content than all categories $(p<0.05)$ except the leaves eaten by the Bwindi gorillas. Our low-protein grasses have significantly higher ADF than the high-protein grasses and the leaves eaten by the Bwindi and Lopé gorillas $(p<0.01)$ but they are not statistically different from the rejected leaf foods and the leaves eaten by the Virunga and Bai Hokou gorillas. As noted, low levels of ADF have been argued to drive food choice in some primate species and in fact, the leaves of the eight species with the lowest ADF content within 


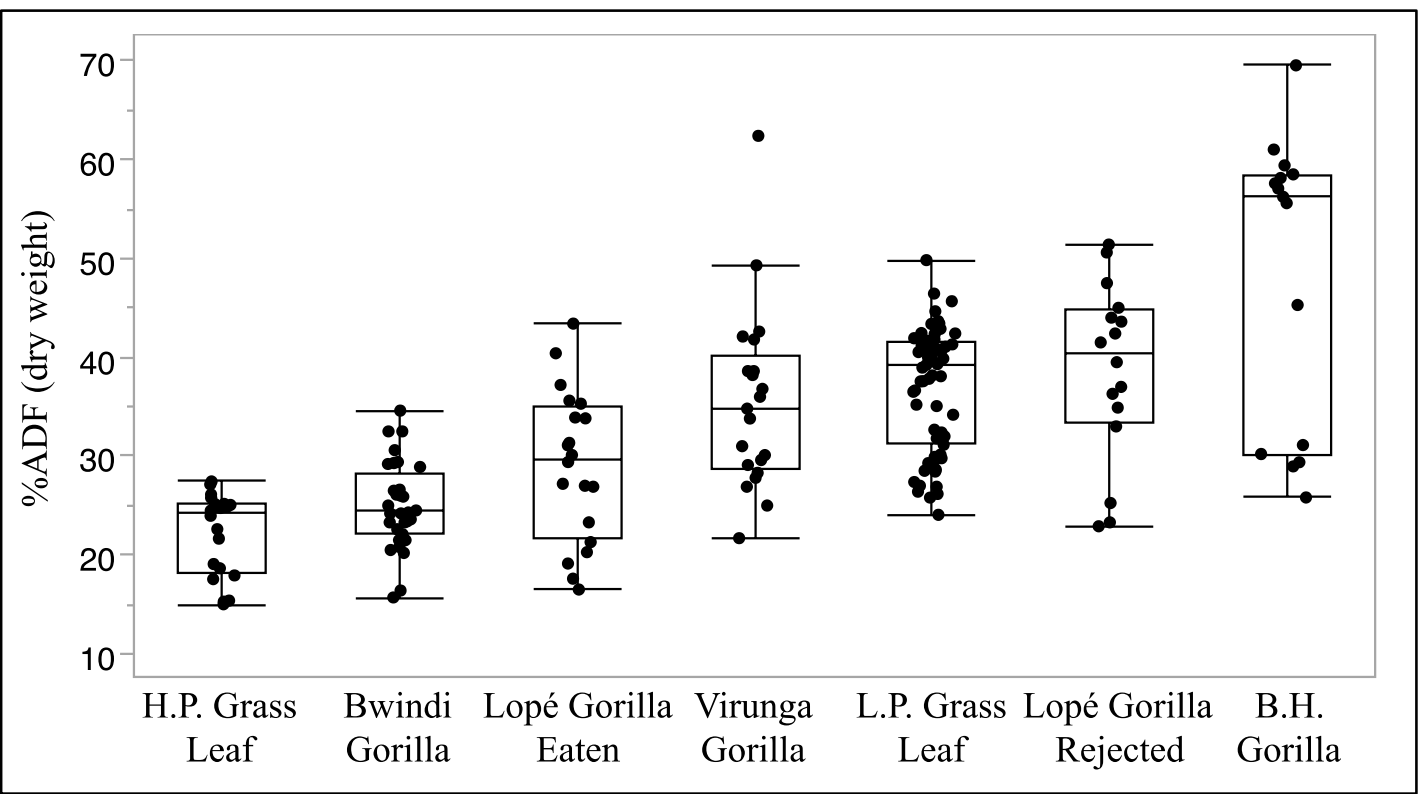

Figure 5. Acid detergent fiber content (\%) of high-protein (H.P.) and low-protein (L.P.) grass leaves compared to leaves eaten, and not eaten, by lowland and mountain gorillas arranged in ascending order by mean value. Boxes represent the $25^{\text {th }}-75^{\text {th }}$ percentiles, the lines within them are the medians, the whiskers show data within 1.5 times the interquartile ranges, and the dots outside of the whiskers are outliers (Wilcoxon/Kruskal-Wallis test, $p<0.0001$ ). Low-protein grass ADF values are significantly higher than high-protein grasses $(p<0.0001)$, Bwindi gorilla leaf foods $(p$ $<0.0001)$, and Lopé gorilla leaf foods $(p=0.0029)$. High-protein grasses are significantly different than the leaves that Lopé gorillas reject $(p=0.0004)$, leaves Lopé gorillas eat $(p=0.0410)$, Virunga gorilla leaf foods $(p<0.0001)$, and Bai Hokou gorilla leaf foods ( $p<0.0001$; Steel-Dwass Method). Gorilla data from Waterman et al., 1983; Rogers et al., 1990; Remis et al., 2001; Rothman et al., 2006.

The ratio of protein to fiber content (protein/fiber) has been proposed as a useful index to gauge the palatability of vegetation for primates (Milton, 1979; Barton et al., 1993; Chapman et al., 2002). Figure 6 combines the data from Figures 4 and 5 to create a spatial representation of these ratios for each food category. As can be seen, high protein/fiber grasses skew higher in nutritional space compared to most gorilla foods whereas our low protein/fiber grasses only intersect with the leaf foods rejected by the Lopé gorillas. 


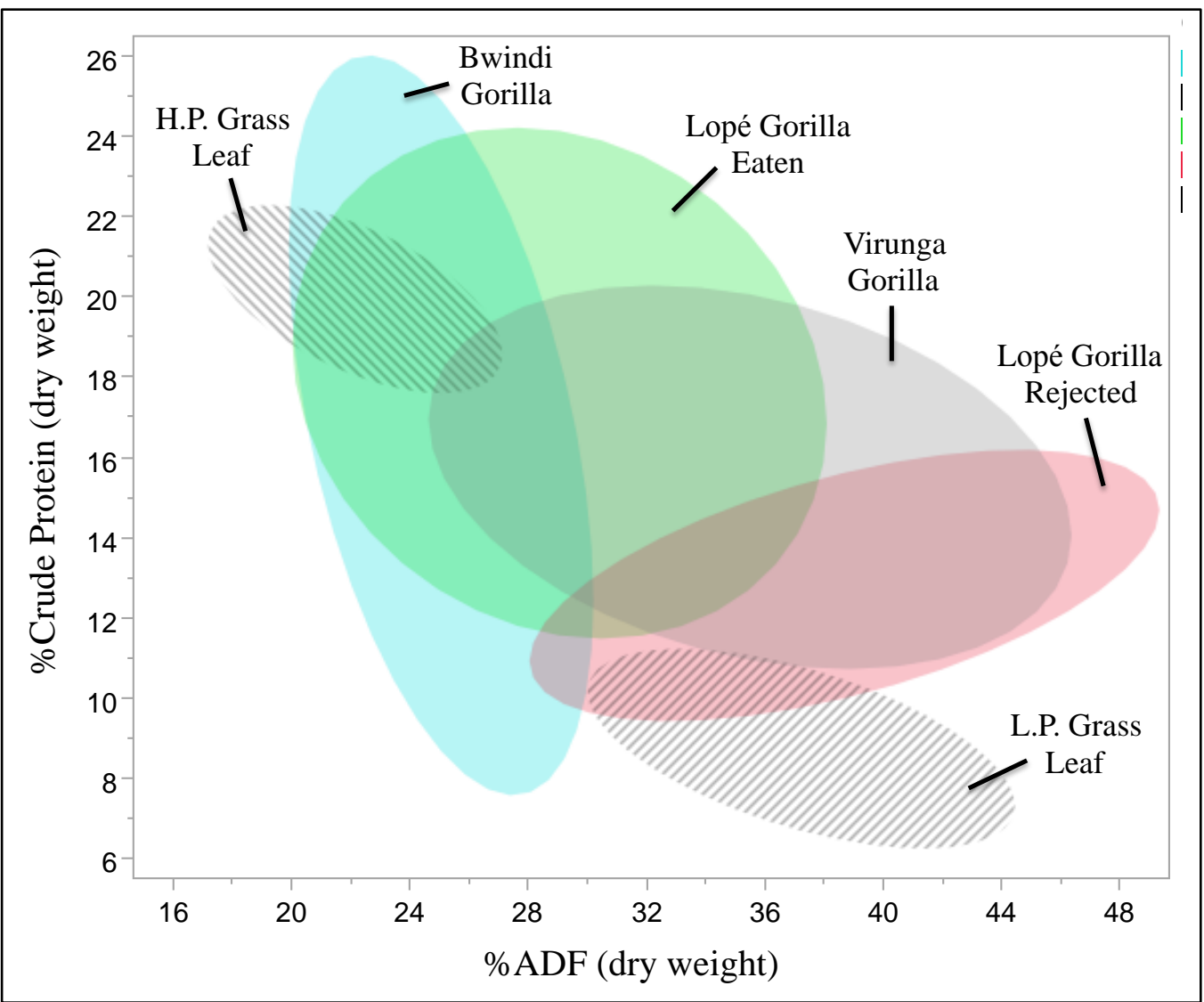

342 Figure 6. Protein/fiber ratios of the leaf foods of gorillas and high-protein (H.P.) and low-protein (L.P.) grass leaves. Higher protein/fiber ratio foods plot nearer to the upper left corner, foods with lower ratios plot nearer to the bottom right corner. Ellipses represent 50\% of each category's distribution. Gorilla data from Waterman et al., 1983;

346 Rogers et al., 1990; Rothman et al., 2006.The Bai Hokou gorilla data have been omitted 347 for clarity.

Toughness can also influence dietary selection for primates and other mammalian herbivores (O'Reagain and Mentis, 1989; O'Reagain, 1993; Hill and Lucas, 1996; Wright, 2005). For instance, O'Reagain (1993) found that the acceptability of grass leaves to grazing sheep at the Dundee Research Station, South Africa, was inversely correlated with tensile strength. Venkarataman et al. (2014) recorded a mean fracture toughness of $2686 \mathrm{~J} / \mathrm{m}^{2}$ (maximum $4197 \mathrm{~J} / \mathrm{m}^{2}$ ) for tall grass leaves consumed by geladas. Presumably, hominins lacking cercopithecoid dentition would have a toughness threshold considerably lower.

Figure 7 shows the toughness values recorded for our low and high protein grasses compared with those for the leafy vegetation consumed by chimpanzees from 359 Kibale National Park, Uganda (Vogel et al., 2008), orangutans from the Ketambe 
360 Research Station, Sumatra (Vogel et al., 2014), and gorillas from the Bwindi 361 Impenetrable and Mgahinga Gorilla National Parks in Uganda (Elgart-Berry, 2004). 362 There are no significant differences in toughness between the leaves of our high363 protein grass samples and the leaves eaten by chimpanzees, gorillas, and orangutans.

364

365

366

367

368

369

370

371

372

373

374

375

376

377

378

379

380

381

382

383

384

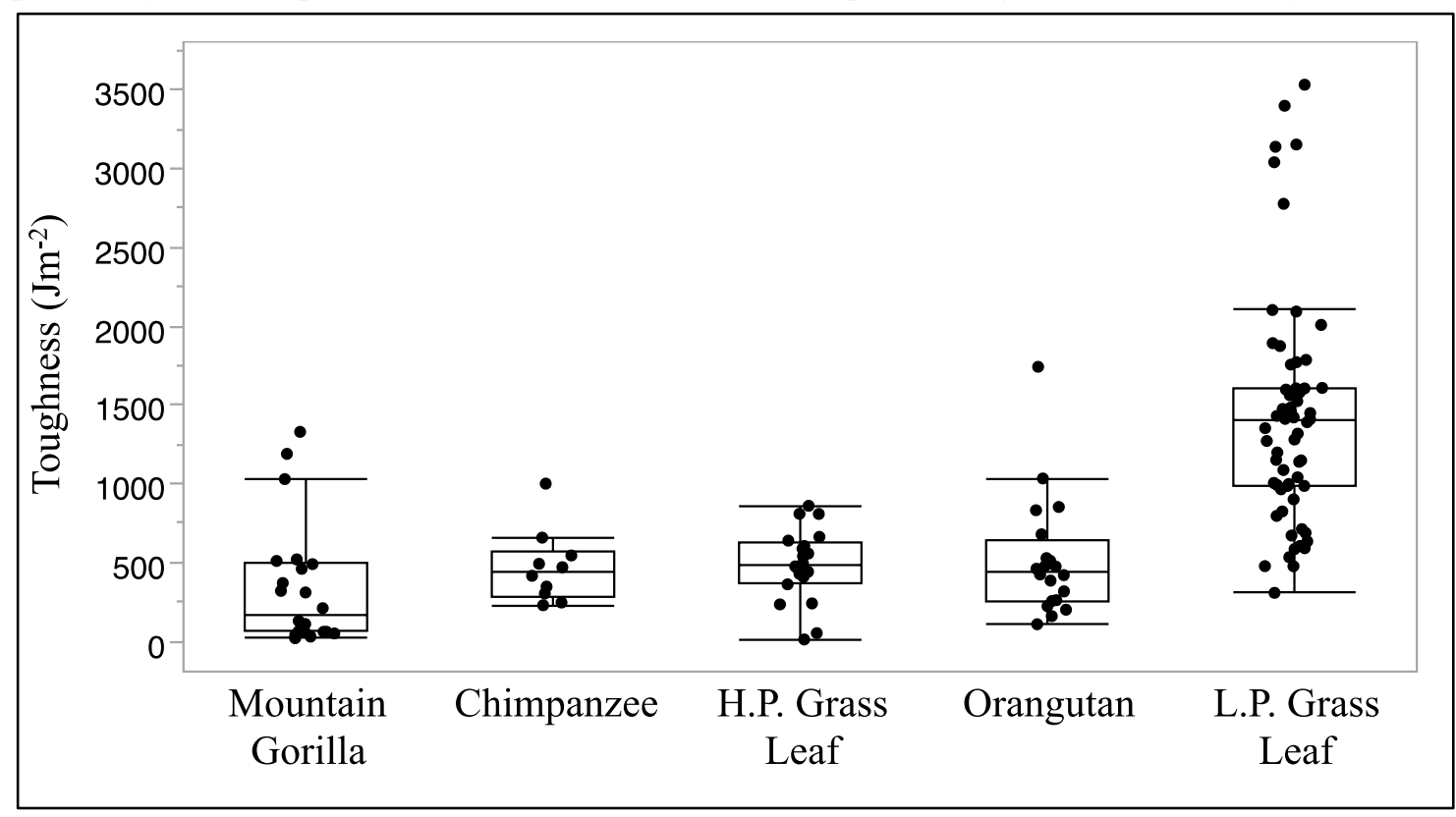

Figure 7. Toughness values of grass leaves compared to the values for leaves consumed by chimpanzees, gorillas, and orangutans arranged in ascending order by mean value. Boxes represent the $25^{\text {th }}-75^{\text {th }}$ percentiles, the lines within them are the medians, the whiskers show data within 1.5 times the interquartile ranges, and the dots outside of the whiskers are outliers. Low-protein (L.P.) grasses have values significantly higher than all other categories ( $p<0.0001$ for all comparisons; Steel-Dwass all pairs).

\section{Primate grass consumption}

The vast majority of primate species, including those used for comparison above, do not rely on grasses as a major source of nutrition mainly due to the fact that most primates live in forested environments where grasses are less abundant, if present at all. Yet, even when grasses are present they are rarely a preferred food. For example, the Fongoli chimpanzees of Senegal that inhabit woodland savanna generally eat few grasses despite their ubiquity within their habitat (Sponheimer et al., 2006). Chimpanzees in Kibale National Park, Uganda, are known to consume the pith of elephant grass (Pennisetum purpureum) when preferred fruits are unavailable, but grass leaves are rarely, if ever eaten (Wrangham et al., 1991, 1998; Conklin-Brittain et al., 1999).

Nonetheless, there are primate species that rely heavily on grass as a source of nutrition. It has long been known that many baboon populations consume almost all 
parts of various grass species: seeds, stem bases, rhizomes, and leaves (DeVore and Washburn, 1963; Altmann and Altmann, 1970; Post, 1982; Altmann et al., 1987; Norton et al., 1987; Barton et al., 1993; Barton and Whiten, 1994; Altmann, 1998). For example, during the Amboseli dry seasons, baboons utilize the stem bases and rhizomes of many grass species but in the weeks after the rains when the grass is in flush, their diet (adults and juveniles) consists of 90\% grass leaves (Altmann and Altmann, 1970; Dougalle et al., 1964). Altmann (1998:82) noted that the fresh leaves of Se. verticillata are a "baboon favorite" and listed many of the species we sampled as being major sources of nutrition for Amboseli baboons including C. plectostachyus, Cynodon dactylon, Sp. ioclados, and Sporobolus spicatus. Similarly, Barton et al. (1993) and Barton and Whiten (1994) observed baboons in Laikipia, Kenya, spending 10.7\% of their average monthly feeding time on the grass leaves of $C$. dactylon, $C$. plectostachyus, and Pennisetum spp. With the exception of Pennisetum, which we did not sample, all of the above grasses are relatively high in protein with low toughness values compared to the many of the other plant tissues in our study.

Also, the gelada, whose diet is often dominated by grass leaf ( $\sim 90 \%)$, clearly demonstrates that large-bodied primates can subsist on grasses (Crook and AldrichBlake, 1968; Dunbar and Dunbar, 1974; Dunbar, 1976; Iwamoto, 1979; Fashing et al., 2014).

\section{The dietary value of grasses beyond their mechanical and nutritional properties}

Poaceae are the fourth largest plant family globally and roughly a tenth of all grass species occur in eastern and southern Africa (van Outdshoorn, 2012). The dominance of grasses in many savannas can be seen when measures of net primary production (NPP) are compared. Grasses often double aboveground NPP compared to trees, particularly in nutrient rich savannas where grass NPP represents two thirds of total NPP. While there is considerable morphological variation among grass species, 412 leaf tissue generally accounts for over $50 \%$ of the aboveground biomass (O'Reagain, 413 1993). In this sense, it is not surprising that $75-90 \%$ of the large mammal biomass 414 living in savanna habitats is supported by grass (Owen-Smith and Danckwerts, 1997).

Altmann (1998) noted that $C$. dactylon, a major food resource for the baboons of Amboseli, is not only valuable from a nutritional standpoint, but also because it is a rhizomatous grass that occurs in thick 'carpets' across large stretches of ground. As such, encounter and harvesting rates are high leading to high energetic yield per invested harvesting time. Sp. spicatus, another species of great importance to both the baboons of Amboseli and Laikipia, forms thick mats in saline soils and is similarly dominant in areas where it is found. In fact, the two wetland transects we sampled in Amboseli are differentiated by the fact that one is bordered by Sp. spicatus and the other by $C$. dactylon mats. 
The fact that $C$. dactylon and Sp. spicatus are known to be major baboon foods is telling in light of the fact that, among our samples, they do not fall within the distribution of high-protein grasses. That being said, these two species (along with Dactyloctenium aegyptium) have the highest protein/fiber ratios within our low-protein category and their consumption by baboons is likely a function of availability as much as it is a result of their inherent nutritional and mechanical properties. It is worth noting that many of our high-protein grasses are the dominant grasses within their respective transects, at least seasonally.

\section{Grass consumption and dental morphology}

It can be argued that specialized dentition with high occlusal relief and pronounced shearing crests is necessary for the efficient and effective comminution of leaves (Lucas, 2004; Atkins, 2009; Ungar, 2010). Indeed, colobine primates (which can be leaf-eating specialists) exhibit 'blade-like' teeth (Kay, 1975; Lucas, 2004; Atkins, 2009; Ungar, 2010). Gelada teeth exhibit increased hypsodonty compared to Papio, their more generalist sister taxon, and this dental morphology is diagnostic for Theropithecus in the fossil record (Eck and Jablonski, 1984; Leakey, 1993).

However, current research is beginning to investigate whether the lack of occlusal relief necessarily indicates a lack of tough, leafy foods in their diets. Winchester et al. (2014) argued that increases in enamel thickness and megadontia are functionally equivalent to hypsodonty in that the increased absolute amount of enamel similarly resists wear over the course of an animal's lifetime. Moreover, australopith dental morphology may be the result of the genetic inability to adopt hypsodonty over a relatively short period of evolutionary time (Grine et al., 2012; Ungar and Hlusko, 2016; Daegling and Grine, 2017). Ungar and Hlusko (2016) noted that the dental adaptations seen in the robust australopiths (molar inflation and thickened enamel) could represent "the evolutionary path of least resistance," arguing that an adaptive shift towards hypsodonty would have required a higher degree of genetic restructuring for such a radical reorganization of dental morphology. Indeed, temporal lags between behavioral shifts and morphological adaptations are seen in other clades such as the East African proboscideans. The fossil record shows a clear and profound dietary shift to $\mathrm{C}_{4}$ grass dominated diets among late gomphotheres and early elephants $\sim 8 \mathrm{Ma}$ and yet, significant increases in lamellar number and hypsodonty do not appear until $\sim 5 \mathrm{Ma}$ (Lister, 2013, 2014; but see Jardine et al., 2012, for discussion of how dietary grit, rather than grass itself, may have selected for mammalian hypsodonty).

What is more, Rabenold and Pearson (2011) examined the phytolith content in the diets of several primates and used the data to predict the molar enamel thickness needed to adequately resist dental attrition. When they compared their predicted values 462 with the observed enamel thickness, they found a strong correlation $\left(\mathrm{R}^{2}=0.87\right)$, 
suggesting that a diet focused on plants with high phytolith content (such as the leaves of grasses) may have selected for the hyper thick dental enamel found in species such as $P$. boisei.

\section{Digestive constraints on the consumption of grass leaf}

Though there are exceptions, the majority of mammalian grazers have specialized digestive systems that enable them to extract energy from the structural carbohydrates found in plant cell walls using both autoenzymatic and alloenzymatic processes. While we will never fully know the digestive capabilities of extinct hominins, the 'funnel-shaped' australopith torso has been argued to indicate a larger gut, and thus the ability to consume more difficult-to-digest (higher fiber) plant foods compared to Homo (Aiello and Wheeler, 1995). While the specialized, multi chambered stomachs of the colobines are clearly adaptations that aid fiber fermentation, other non-colobine primates have an excellent capacity for so-called hind-gut fermentation. Chimpanzees, for example, are considered 'high fermenters' of fiber (particularly hemicelluloses) among the hominoids (Conklin-Brittain et al., 2006) and it is probably fair to assume that ancient hominins had some ability to extract energy from dietary fiber. Regardless, many of the grasses we examined are relatively low in ADF and when protein/fiber ratios are taken into account, it becomes clear that many grass leaves fall within the ranges of non-grass leaf foods consumed by other hominoids (Figure 6).

\section{Future considerations}

We recognize that levels of protein and fiber alone do not dictate food choice in herbivores and that the nutritional quality of any potential food is more difficult to quantify. Other macronutrients such as non-structural carbohydrates (e.g., starches, sugars) and lipids as well as water content and essential minerals such as calcium, phosphorous, and sodium are important factors to consider when assessing the potential value of any given food resource (Sniffen et al., 1992; McDowell and Valle, 2000). Nutritional quality is also impacted by antifeedants such as lignin and tannins, plant secondary metabolites (true toxins), and biogenic silica that can both impede nutrient uptake and cause toxic effects for herbivore consumers (Robbins, 1993; Reed et al., 2000). Grass leaves, while generally lower in secondary compounds than tree leaves, can accumulate high amounts of silica in their leaf tissues (Coughenour, 1985), and can increase concentrations in response to grazing pressure (Jones and Handreck, 1967; these variables as possible in order to obtain a more accurate picture of dietary quality.

Furthermore, the effects of season and habitat play a role in determining the nutritional and mechanical properties of plant foods throughout their life cycle. Here, 
we only present data for leaf foods during the wet season (see Methods). Any assessment of the potential for plant foods to act as staple components of diet need to 504 incorporate these spatial and temporal effects, notably the tendency for the nutritional 505 quality of leafy vegetation in savanna habitats to decline during dry seasons (Cooper et 506 al., 1988; Georgiadis and McNaughton, 1990). Seasonal effects on leafy vegetation are among the reasons that USOs are often argued to have been important foods for 508 hominins because they are thought to be relatively resistant to temporal fluctuations in nutritional quality (Laden and Wrangham, 2005). However, it must be noted that 'USO' is a somewhat artificial category considering the wide range of forms that underground storage organs can take (e.g., fleshy, starch filled tubers vs. tough rhizomes) and further study requires separating USOs into multiple categories. From a spatial perspective, habitat differences at both the local and regional level almost certainly affect the nutritional and mechanical properties of vegetation and this may be particularly important for our understanding of hominin dietary ecology. Could it be possible that the different carbon isotopic compositions of $P$. boise $i$ and $P$. robustus are the result of nutritional and mechanical differences between the available $\mathrm{C}_{4}$ vegetation within their respective habitats? Though we suspect that this might be the case, our understanding of the paleolandscapes on which these hominins lived and, particularly, the mechanical and nutritional properties of the available vegetation, is not sufficiently advanced at this point to address this question.

\section{Conclusion}

Stable carbon isotope analyses have revealed that $\mathrm{C}_{4}$ foods were consumed by many hominin species and it is a fair assumption that the bulk of those resources came in the form of plant tissues. Early hominins were likely to be generalist feeders that opportunistically consumed resources based on their seasonal availability (Knott, 2005).

The USOs of $\mathrm{C}_{4}$ sedges and $\mathrm{C}_{4}$ grass seeds were almost certainly part of the broader hominin dietary repertoire just as they are for baboons today (Jolly, 1970; Norton et al., 1987; Altmann, 1998; Dominy et al., 2008). However, a combination of the limited seasonal availability of grass seeds, the lack of dental microwear evidence supporting USO consumption, and their nutritional/mechanical properties reported here, make it unlikely that they could solely account for all of the $\mathrm{C}_{4}$-derived carbon in high- $\mathrm{C}_{4}$ species like $P$. boisei. Our data show that grass leaves should not be treated as a 'one size fits all' category as many are less tough, higher in protein, and lower in fiber than other potential plant foods on some savanna landscapes. This, coupled with their great abundance, means we should not summarily exclude grass leaves from reconstructions of hominin diets. Indeed, we know of no living large-bodied mammal (excepting carnivores that prey heavily on grazing herbivores) with a $\mathrm{C}_{4}$ isotopic 
541 signature like the one seen in $P$. boisei that does not eat grass leaf extensively, if not 542 exclusively. It is not clear to us that hominins are exceptions to this mammalian rule. 543 Regardless, if we hope to build better models of early hominin dietary behavior, the 544 inherent variation of grass leaf properties (and of other potential foods), as 545 demonstrated here, needs to be considered.

\section{Acknowledgments:}

548 We thank James Louden, Alex Cowper, Nicholas Gakuu, and, especially, Antje 549 Hutschenreuther for their help in the field. We would also like to thank Lee Berger, the 550 Cradle Nature Reserve, Kenjara Lodge, the British Institute in Eastern Africa, the 551 Kenyan Wildlife Service and the National Museums of Kenya. This work was 552 supported by The Leakey Foundation (grant \# 1134801-1-75898), the Wenner-Gren 553 Foundation (grant \#8965), the National Science Foundation (grant \# 1134589-1554 75806), the Max Planck Society, and the University of Colorado Boulder. It was also 555 funded in part by the European Research Council (ERC) under the European Union's 556 Horizon 2020 research and innovation program under grant agreement number STG557677576 ("HARVEST"). This is a research product, in whole or in part, of the 558 Nutritional and Isotopic Ecology Lab (NIEL) at CU Boulder.

\section{References}

Aiello, L.C., Wheeler, P., 1995. The expensive-tissue hypothesis: the brain and the digestive system in human and primate evolution. Curr. Anthropol. 36, 199-221. Altmann, S., Post, D., Klein, D., 1987. Nutrients and toxins of plants in Amboseli, Kenya. African J. Ecol. 25, 279-293.

Altmann, S.A., 1998. Foraging for Survival: Yearling Baboons in Africa. University of Chicago Press, Chicago.

Altmann, S.A., Altmann, J., 1973. Baboon Ecology. University of Chicago Press, Chicago.

Atkins, T., 2009. The Science and Engineering of Cutting: The Mechanics and Processes of Separating, Scratching and Puncturing Biomaterials, Metals and NonMetals. Butterworth-Heinemann, Oxford, UK.

Barton, R., Whiten, A., Byrne, R., English, M., 1993. Chemical composition of baboon plant foods: implications for the interpretation of intra-and interspecific differences in diet. Folia Primatol. 61, 1-20.

Barton, R.A., Whiten, A., 1994. Reducing complex diets to simple rules: food selection by olive baboons. Behav. Ecol. Sociobiol. 35, 283-293.

Cerling, T.E., Mbua, E., Kirera, F.M., Manthi, F.K., Grine, F.E., Leakey, M.G., of East Africa. Proc. Natl. Acad. Sci. 108, 9337-9341. 
580 Chapman, C.A., Chapman, L.J., Bjorndal, K.A., Onderdonk, D.A., 2002. Application of 581 protein-to-fiber ratios to predict colobine abundance on different spatial scales. Int. J.

582 Primatol. 23, 283-310.

583 Charnov, E.L., 1976. Optimal foraging, the marginal value theorem. Theor. Popul. Biol.

584 9, 129-136.

585 Conklin-Brittain, N., Knott, C., Wrangham, R., 2006. Energy intake by wild

586 chimpanzees and orangutans: methodological considerations and a preliminary

587 comparison. Cm. S. Bio. Evol. Anth. 1, 445-472.

588 Conklin-Brittain, N.L., Wrangham, R.W., Hunt, K.D., 1998. Dietary response of

589 chimpanzees and cercopithecines to seasonal variation in fruit abundance. II.

590 Macronutrients. Int. J. Primatol. 19, 971-998.

591 Constantino, P.J., Lee, J.J.-W., Chai, H., Zipfel, B., Ziscovici, C., Lawn, B.R., Lucas,

592 P.W., 2010. Tooth chipping can reveal the diet and bite forces of fossil hominins. Biol.

593 Letters 6, 826-829.

594 Constantino, P.J., Lee, J.J.-W., Morris, D., Lucas, P.W., Hartstone-Rose, A., Lee, W.-

595 K., Dominy, N.J., Cunningham, A., Wagner, M., Lawn, B.R., 2011. Adaptation to

596 hard-object feeding in sea otters and hominins. J. Hum. Evol. 61, 89-96.

597 Cooper, S.M., Owen-Smith, N., Bryant, J.P., 1988. Foliage acceptability to browsing

598 ruminants in relation to seasonal changes in the leaf chemistry of woody plants in a

599 South African savanna. Oecologia 75, 336-342.

600 Coughenour, M.B., 1985. Graminoid responses to grazing by large herbivores:

601 adaptations, exaptations, and interacting processes. Ann. Mo. Bot. Gard. 72, 852-863.

602 Crook, J.H., Aldrich-Blake, P., 1968. Ecological and behavioural contrasts between

603 sympatric ground dwelling primates in Ethiopia. Folia Primatol. 8, 192-227.

604 Daegling, D.J., Grine, F.E., 2017. Feeding behavior and diet in Paranthropus boisei:

605 the limits of functional inference from the mandible. In: Marom, A., Hovers, E. (Eds.),

606 Human Paleontology and Prehistory: Contributions in Honor of Yoel Rak. Springer

607 International Publishing, Cham, pp. 109-125.

608 Demes, B., Creel, N., 1988. Bite force, diet, and cranial morphology of fossil hominids.

609 J. Hum. Evol. 17, 657-670.

610 DeVore, I., Washburn, S.L., 1963. Baboon ecology and human evolution. In: Howel,

611 F.C., Bourlière, F. (Eds.), African Ecology and Human Evolution. Viking Fund

612 Publications in Anthropology No. 36, New York, pp. 335-367.

613 Dominy, N.J., 2012. Hominins living on the sedge. Proc. Natl. Acad. Sci. 109, 20171-

61420172.

615 Dominy, N.J., Vogel, E.R., Yeakel, J.D., Constantino, P., Lucas, P.W., 2008.

616 Mechanical properties of plant underground storage organs and implications for dietary

617 models of early hominins. Evol. Biol. 35, 159-175. 
618 Dunbar, R., Dunbar, E., 1974. Ecological relations and niche separation between

619 sympatric terrestrial primates in Ethiopia. Folia Primatol. 21, 36-60.

620 Eck, G.G., Jablonski, N.G., 1984. A reassessment of the taxonomic status and phyletic

621 relationships of Papio baringensis and Papio quadratirostris (Primates:

622 Cercopithecidae). Am. J. Phys. Anthropol. 65, 109-134.

623 Elgart-Berry, A., 2004. Fracture toughness of mountain gorilla (Gorilla gorilla

624 beringei) food plants. Am. J. Primatol. 62, 275-285.

625 Fashing, P.J., Nguyen, N., Venkataraman, V.V., Kerby, J.T., 2014. Gelada feeding

626 ecology in an intact ecosystem at Guassa, Ethiopia: variability over time and

627 implications for theropith and hominin dietary evolution. Am. J. Phys. Anthropol. 155, $6281-16$.

629 Grine, F.E., Sponheimer, M., Ungar, P.S., Lee-Thorp, J., Teaford, M.F., 2012a. Dental

630 microwear and stable isotopes inform the paleoecology of extinct hominins. Am. J.

631 Phys. Anthropol. 148, 285-317.

632 Grine, F.E., Sponheimer, M., Ungar, P.S., Lee-Thorp, J., Teaford, M.F., 2012b. Dental

633 microwear and stable isotopes inform the paleoecology of extinct hominins. Am. J.

634 Phys. Anthropol. 148, 285-317.

635 Gunther, K.A., Shoemaker, R.R., Frey, K.L., Haroldson, M.A., Cain, S.L., Van Manen,

636 F.T., Fortin, J.K., 2014. Dietary breadth of grizzly bears in the Greater Yellowstone

637 Ecosystem. Ursus 25, 60-72.

638 Harmand, S., Lewis, J.E., Feibel, C.S., Lepre, C.J., Prat, S., Lenoble, A., Boës, X.,

639 Quinn, R.L., Brenet, M., Arroyo, A., 2015. 3.3-million-year-old stone tools from

640 Lomekwi 3, West Turkana, Kenya. Nature 521, 310-315.

641 Hatley, T., Kappelman, J., 1980. Bears, pigs, and Plio-Pleistocene hominids: a case for

642 the exploitation of belowground food resources. Hum. Ecol. 8, 371-387.

643 Hernandez-Aguilar, R.A., Moore, J., Pickering, T.R., 2007. Savanna chimpanzees use

644 tools to harvest the underground storage organs of plants. Proc. Natl. Acad. Sci. 104,

$645 \quad 19210-19213$.

646 Hill, D.A., Lucas, P.W., 1996. Toughness and fiber content of major leaf foods of

647 Japanese macaques (Macaca fuscata yakui) in Yakushima. Am. J. Primatol.38, 221-

648231.

649 Hylander, W.L., 1988. Implications of in vivo experiments for interpreting the

650 functional significance of "robust" australopithecine jaws, in Grine, F. (Ed.),

651 Evolutionary History of the "Robust" Australopithecines. Transaction Publishers, New

652 York, pp. 55-83.

653 Iwamoto, T., 1979. Ecological and sociological studies of gelada baboons. Feeding

654 ecology. Contrib. Primatol. 16, 279-330. 
655 Jacobs, B.F., Kingston, J.D., Jacobs, L.L., 1999. The origin of grass-dominated

656 ecosystems. Ann. Mo. Bot. Gard. 86, 590-643.

657 Janis, C., 1976. The evolutionary strategy of the Equidae and the origins of rumen and

658 cecal digestion. Evolution, 30, 757-774.

659 Janis, C.M., Fortelius, M., 1988. On the means whereby mammals achieve increased

660 functional durability of their dentitions, with special reference to limiting factors. Biol

661 Rev. 63, 197-230.

662 Jardine, P.E., Janis, C.M., Sahney, S., Benton, M.J., 2012. Grit not grass: concordant

663 patterns of early origin of hypsodonty in Great Plains ungulates and Glires.

664 Palaeogeogr. Palaeoclimatol. Palaeoecol. 365, 1-10.

665 JMP $^{\circledR}$, Version 13.0. SAS Institute Inc., Cary, NC, 1989-2017.

666 Jolly, C.J., 1970. The seed-eaters: a new model of hominid differentiation based on a

667 baboon analogy. Man 5, 5-26.

668 Jones, L., Handreck, K., 1967. Silica in soils, plants, and animals. Adv. Agron. 19,

$669 \quad 107-149$.

670 Kay, R.F., 1975. The functional adaptations of primate molar teeth. Am. J. Phys.

671 Anthropol. 43, 195-215.

672 Kay, R.F., 1985. Dental evidence for the diet of Australopithecus. A. Rev. Anthropol.

$673 \quad 14,315-341$.

674 Knott, C.D., 2005. Energetic responses to food availability in the great apes:

675 implications for hominin evolution, in: Brockman, D.K., van Schaik, C.P. (Eds.),

676 Seasonality in Primates: Studies of Living and Extinct Human and Non-Human

677 Primates, Cambridge University Press, New York, pp. 351-378.

678 Laden, G., Wrangham, R., 2005. The rise of the hominids as an adaptive shift in

679 fallback foods: plant underground storage organs (USOs) and australopith origins. J.

680 Hum. Evol. 49, 482-498.

681 Lambert, J.E., Rothman, J.M., 2015. Fallback foods, optimal diets, and nutritional

682 targets: Primate responses to varying food availability and quality. A. Rev. Anthropol.

$68344,493-512$.

684 Langer, P., 1974. Stomach evolution in the Artiodactyla. Mammalia 38, 295-314.

685 Leakey, L.S., 1959. A new fossil skull from Olduvai. Nature 184, 491-493.

686 Leakey, M.G., 1993. Evolution of Theropithecus in the Turkana basin, in: Jablonski, 687 N.G. (Ed.), Theropithecus: The Rise and Fall of a Primate Genus. Cambridge

688 University Press, New York, pp. 85-123.

689 Lee-Thorp, J., Likius, A., Mackaye, H.T., Vignaud, P., Sponheimer, M., Brunet, M., 690 2012a. Isotopic evidence for an early shift to $\mathrm{C} 4$ resources by Pliocene hominins in

691 Chad. Proc. Natl. Acad. Sci. 109, 20369-20372. 
692 Lee-Thorp, J., Likius, A., Mackaye, H.T., Vignaud, P., Sponheimer, M., Brunet, M., 693 2012b. Isotopic evidence for an early shift to C4 resources by Pliocene hominins in

694 Chad. Proc. Natl. Acad. Sci. 109, 20369-20372.

695 Levin, N.E., Haile-Selassie, Y., Frost, S.R., Saylor, B.Z., 2015. Dietary change among

696 hominins and cercopithecids in Ethiopia during the early Pliocene. Proc. Natl. Acad.

697 Sci. 112, 12304-12309.

698 Lister, A.M., 2013. The role of behaviour in adaptive morphological evolution of

699 African proboscideans. Nature 500, 331-334.

700 Lister, A.M., 2014. Behavioural leads in evolution: evidence from the fossil record.

701 Biol. J. Linn. Soc. 112, 315-331.

702 Lucas, P.W., 2004. Dental Functional Morphology: How Teeth Work. Cambridge

703 University Press, New York.

704 Macho, G.A., 2014. Baboon feeding ecology informs the dietary niche of Paranthropus

705 boisei. PLoS One 9, e84942.

706 Macho, G.A., 2015. Pliocene hominin biogeography and ecology. J. Hum. Evol. 87, $707 \quad 78-86$.

708 McDowell, L., Valle, G., 2000. Major minerals in forages, in: Givens, D.I., Owen, E., 709 Axford, R.F.E., Omed, H.M. (Eds.), Forage Evaluation in Ruminant Nutrition. CABI

710 Publishing, New York, pp. 373-397.

711 McNaughton, S., Georgiadis, N.J., 1986. Ecology of African grazing and browsing

712 mammals. Annu. Rev. of Ecol. Syst. 17, 39-66.

713 McPherron, S.P., Alemseged, Z., Marean, C.W., Wynn, J.G., Reed, D., Geraads, D.,

714 Bobe, R., Béarat, H.A., 2010. Evidence for stone-tool-assisted consumption of animal

715 tissues before 3.39 million years ago at Dikika, Ethiopia. Nature 466, 857-860.

716 Milton, K., 1979. Factors influencing leaf choice by howler monkeys: a test of some

717 hypotheses of food selection by generalist herbivores. Am. Nat. 114, 362-378.

718 Norton, G.W., Rhine, R.J., Wynn, G.W., Wynn, R.D., 1987. Baboon diet: a five-year

719 study of stability and variability in the plant feeding and habitat of the yellow baboons

720 (Papio cynocephalus) of Mikumi National Park, Tanzania. Folia Primatol. 48, 78-120.

721 O'Reagain, P., Mentis, M., 1989. The effect of plant structure on the acceptability of

722 different grass species to cattle. Journal of the Grassland Society of Southern Africa 6,

723 163-170.

724 O'Reagain, P.J., 1993. Plant structure and the acceptability of different grasses to sheep.

725 J. Range Manage. 46, 232-236.

726 Oates, J.F., Whitesides, G.H., Davies, A.G., Waterman, P.G., Green, S.M., Dasilva,

727 G.L., Mole, S., 1990. Determinants of variation in tropical forest primate biomass: new

728 evidence from West Africa. Ecology 71, 328-343.

729 Oudtshoorn, F.v., 1999. Guide to Grasses of Southern Africa. Briza Publications,

730 Pretoria. 
731 Peters, C.R., Vogel, J.C., 2005. Africa's wild $\mathrm{C}_{4}$ plant foods and possible early hominid 732 diets. J. Hum. Evol. 48, 219-236.

733 Post, D.G., 1982. Feeding behavior of yellow baboons (Papio cynocephalus) in the

734 Amboseli National Park, Kenya. Int. J. Primatol. 3, 403-430.

735 Prize, C., Workings, I., Classics, P., Portals, P., Statements, S., 2013. African hominin

736 stable isotopic data do not necessarily indicate grass consumption. Poc. Natl. Acad. Sci.

737 110, 17163-17164.

738 Rabenold, D., Pearson, O.M., 2011. Abrasive, silica phytoliths and the evolution of

739 thick molar enamel in primates, with implications for the diet of Paranthropus boisei.

740 PLoS One 6, e28379.

741 Raia, P., 2004. Morphological correlates of tough food consumption in large land carnivores.

742 Ital. J. Zool. 71, 45-50.

Rak, Y., 1988. On variation in the masticatory system of Australopithecus boisei. in Grine, F.

745 (Ed.), Evolutionary History of the "Robust" Australopithecines. Transaction Publishers, New

746 York, pp.193-198.

747 Rak, Y., 2014. The Australopithecine Face. Academic Press, New York.

748 Reed, J., Krueger, C., Rodriguez, G., Hanson, J., 2000. Secondary plant compounds and

749 forage evaluation. in, Givens, D.I., Owen, E., Axford, R.F.E. (Eds.), Forage Evaluation

750 in Ruminant Nutrition. CABI Publishing, New York, pp. 433-448.

751 Reed, K.E., Spencer, L.M., Rector, A.L., 2013. Faunal approaches in early hominin

752 paleoecology. in, Sponheimer, M. (Ed.), Early Hominin Paleoecology. University

753 Press of Colorado, Boulder, pp. 3-34.

754 Remis, M.J., Dierenfeld, E., Mowry, C., Carroll, R., 2001. Nutritional aspects of

755 western lowland gorilla (Gorilla gorilla gorilla) diet during seasons of fruit scarcity at

756 Bai Hokou, Central African Republic. Int. J. Primatol. 22, 807-836.

757 Robbins, C., 2012. Wildlife Feeding and Nutrition. Academic Press, New York.

758 Rogers, M.E., Maisels, F., Williamson, E.A., Fernandez, M., Tutin, C.E., 1990. Gorilla

759 diet in the Lopé Reserve, Gabon. Oecologia 84, 326-339.

760 Rothman, J.M., Chapman, C.A., Struhsaker, T.T., Raubenheimer, D., Twinomugisha,

761 D., Waterman, P.G., 2015. Long-term declines in nutritional quality of tropical leaves.

762 Ecology 96, 873-878.

763 Rothman, J.M., Dierenfeld, E.S., Molina, D.O., Shaw, A.V., Hintz, H.F., Pell, A.N.,

764 2006. Nutritional chemistry of foods eaten by gorillas in Bwindi Impenetrable National

765 Park, Uganda. Am. J. Primatol.68, 675-691.

766 Sage, R.F., 2004. The evolution of C4 photosynthesis. New Phytol. 161, 341-370.

767 Sage, R.F., Sage, T.L., Pearcy, R.W., Borsch, T., 2007. The taxonomic distribution of

$768 \mathrm{C}_{4}$ photosynthesis in Amaranthaceae sensu stricto. Am. J. Bot. 94, 1992-2003. 
Scholes, R., Archer, S., 1997. Tree-grass interactions in savannas 1. Annu. Rev. Ecol. Syst. 28, 517-544.

771 Simpson, S.J., Raubenheimer, D., 2012. The Nature of Nutrition: A Unifying Framework from Animal Adaptation to Human Obesity. Princeton University Press,

774 Sniffen, C., O'connor, J., Van Soest, P., Fox, D., Russell, J., 1992. A net carbohydrate and protein system for evaluating cattle diets: II. Carbohydrate and protein availability. J. Anim. Sci. 70, 3562-3577. M.G., Lee-Thorp, J.A., Manthi, F.K., Reed, K.E., Wood, B.A., 2013. Isotopic evidence of early hominin diets. Proc. Natl. Acad. Sci. 110, 10513-10518.

780 Sponheimer, M., Loudon, J., Codron, D., Howells, M., Pruetz, J.D., Codron, J., De 781 Ruiter, D., Lee-Thorp, J.A., 2006. Do "savanna" chimpanzees consume $\mathrm{C}_{4}$ resources?

782 J. Hum. Evol. 51, 128-133.

783 Stirton, R., 1947. Observations on evolutionary rates in hypsodonty. Evolution 1, 3278441.

785 Stohlgren, T.J., Falkner, M., Schell, L., 1995. A modified-Whittaker nested vegetation 786 sampling method. P. Ecol. 117, 113-121.

787 Strait, D.S., Constantino, P., Lucas, P.W., Richmond, B.G., Spencer, M.A., Dechow, 788 P.C., Ross, C.F., Grosse, I.R., Wright, B.W., Wood, B.A., Weber, G.W., Wang, Q., 789 Byron, C., Slice, D.E., Chalk, J., Smith, A.L., Smith, L.C., Wood, S., Berthaume, M., 790 Benazzi, S., Dzialo, C., Tamvada, K., Ledogar, J.A., 2013. Viewpoints: diet and dietary 791 adaptations in early hominins: the hard food perspective. Am. J. Phys. Anthropol. 151, $792 \quad 339-355$.

793 Strait, D.S., Wright, B.W., Richmond, B.G., Ross, C.F., Dechow, P.C., Spencer, M.A., 794 Wang, Q., 2008. Craniofacial strain patterns during premolar loading: implications for 795 human evolution. in, Vinyard, C., Ravosa, M.J., Wall, C. (Eds.), Primate Craniofacial 796 Function and Biology. Springer, New York, pp. 173-198.

797 Tobias, P.V., 1967. Olduvai Gorge. Cambridge University Press, Cambridge.

798 Ungar, P., Hlusko, L., 2016. The evolutionary path of least resistance. Science 353, 2979930.

800 Ungar, P.S., 2010. Mammal teeth: origin, evolution, and diversity. JHU Press.

801 Ungar, P.S., Grine, F.E., Teaford, M.F., 2008. Dental microwear and diet of the Plio-

802 Pleistocene hominin Paranthropus boisei. PLoS One 3, e2044.

803 Ungar, P.S., Krueger, K.L., Blumenschine, R.J., Njau, J., Scott, R.S., 2012. Dental

804 microwear texture analysis of hominins recovered by the Olduvai Landscape

805 Paleoanthropology Project, 1995-2007. J. Hum. Evol. 63, 429-437.

806 Ungar, P.S., Sponheimer, M., 2011. The diets of early hominins. Science 334, 190-193. 
van der Merwe, N.J., Masao, F.T., Bamford, M.K., 2008. Isotopic evidence for

808 contrasting diets of early hominins Homo habilis and Australopithecus boisei of

809 Tanzania. S. Afr. J. Sci. 104, 153-155.

810 Van Soest, P., Jones, L., 1968. Effect of silica in forages upon digestibility. J. Dairy

811 Sci. 51, 1644-1648.

812 Venkataraman, V.V., Glowacka, H., Fritz, J., Clauss, M., Seyoum, C., Nguyen, N.,

813 Fashing, P.J., 2014. Effects of dietary fracture toughness and dental wear on chewing

814 efficiency in geladas (Theropithecus gelada). Am. J. Phys. Anthropol. 155, 17-32.

815 Vogel, E.R., van Woerden, J.T., Lucas, P.W., Atmoko, S.S.U., van Schaik, C.P.,

816 Dominy, N.J., 2008. Functional ecology and evolution of hominoid molar enamel

817 thickness: Pan troglodytes schweinfurthii and Pongo pygmaeus wurmbii. J. Hum. Evol.

$81855,60-74$.

819 Vogel, E.R., Zulfa, A., Hardus, M., Wich, S.A., Dominy, N.J., Taylor, A.B., 2014.

820 Food mechanical properties, feeding ecology, and the mandibular morphology of wild

821 orangutans. J. Hum. Evol. 75, 110-124.

822 Waterman, P.G., Choo, G.M., Vedder, A.L., Watts, D., 1983. Digestibility, digestion-

823 inhibitors and nutrients of herbaceous foliage and green stems from an African montane

824 flora and comparison with other tropical flora. Oecologia 60, 244-249.

825 White, T.E., 1959. The endocrine glands and evolution, no. 3: os cementum

826 hypsodonty, and diet. Contributions from the Museum of Paleontology, The University

827 of Michigan. 13, 211-265.

828 Wood, B., Constantino, P., 2007. Paranthropus boisei: fifty years of evidence and

829 analysis. Am. J. Phys. Anthropol. 134, 106-132.

830 Wrangham, R., Cheney, D., Seyfarth, R., Sarmiento, E., 2009. Shallow-water habitats

831 as sources of fallback foods for hominins. Am. J. Phys. Anthropol. 140, 630-642.

832 Wrangham, R., Conklin-Brittain, N., Chapman, C., Hunt, K., Milton, K., Rogers, E.,

833 Whiten, A., Barton, R., 1991. The significance of fibrous foods for Kibale Forest

834 chimpanzees [and discussion]. Phil. Trans. R. Soc. B. 334, 171-178.

835 Wrangham, R.W., Conklin-Brittain, N.L., Hunt, K.D., 1998. Dietary response of

836 chimpanzees and cercopithecines to seasonal variation in fruit abundance. I.

837 Antifeedants. Int. J. Primatol. 19, 949-970.

838 Wright, B.W., 2005. Craniodental biomechanics and dietary toughness in the genus

839 Cebus. J. Hum. Evol. 48, 473-492.

840 Yeakel, J.D., Bennett, N.C., Koch, P.L., Dominy, N.J., 2007. The isotopic ecology of

841 African mole rats informs hypotheses on the evolution of human diet. Proc. R. Soc.

842 Lond. B. 274, 1723-1730.

843 Yeakel, J.D., Dominy, N.J., Koch, P.L., Mangel, M., 2014. Functional morphology,

844 stable isotopes, and human evolution: a model of consilience. Evolution 68, 190-203. 